\title{
A Renaissance in the Management of HRM in Higher Technical Institutions
}

\author{
G.Rathidevi ${ }^{1}$, Dr. G. Brindha ${ }^{2}$ \\ \{rathiharini85@gmail.com¹, bkk28@yahoo.co.in $\left.{ }^{2}\right\}$ \\ Research Scholar, Department of Management studies, Bharath Institute of Higher Education and \\ Research, Chennai ${ }^{1}$, Professor and Head, Department of Management studies, \\ Dr. M.G.R. Educational and Research Institute, Chennai $^{2}$
}

\begin{abstract}
Human useful resource management in schooling is very significant and toy with it'd result in difficulty. This is because teaching personnel's are the main tool for attaining academic dreams and national development, consequently. Human assets are the key to speedy socio-economic improvement and green service shipping. That's why this paper harassed that without an adequate, professional and nicely-encouraged group of workers running inside a valid human aid management programme, improvement isn't feasible. Every instructional gadget at each degree relies upon heavily on the human resources for execution of its programme. The function of human useful resource management in schooling consists of group of workers maintenance, group of workers relations, group of workers improvement, procurement of team of workers and process performance praise. The challenges of human resource management consist of poor running circumstance, incessant transfer of teacher among others, trouble of staffing, funding. To cope with the diagnosed trials, the following endorsements have been made. Education should be made appealing by way of growing a conducive atmosphere for teachers. More government consideration is needed for training zone via improved feature as training retains the basis for the progress of all different sectors of the society. A united profits structure need to be made for all classifications of educators within the schooling sectors.
\end{abstract}

Keywords: Education Institutions, Human resource management in education, Renaissance.

\section{Introduction}

Education is vital to all of us in a country. It plays a essential position to alternate the state of the nation. No country can carry a revolution in it until it's human beings are knowledgeable sufficient to fulfill the experiments. Education makes a person comprehend approximately himself and his goals and to how to reap them. Basically, schooling is separated into 3 agencies. The training which clarifies a society is referred to as 'social education'. The education which develops a character inside a man himself is known as 'religious training'. The academic difficulty with the professionalism is called 'vocational education'. No nation could make the progression unless it promotes all these kinds of education. Learners want to be guided by human and social values, to mix with intelligent people, to unravel the unknown, to be in touch with the fast paced developments and to 
understand the essence of life. They seek quality education and prestigious qualifications leading to a secure and a comfortable career.

Education all over the world is still looked upon as a harbinger of all other changes social, cultural, economic, scientific and technical. One of the changes that are envisaged is that knowledge will not only be a source of authority, but also the capital for further development. Efforts must, therefore, be directed to develop human resources in a manner that they become sources of strength and wealth to the country. It would be a challenge to harness modern technologies for an all-round development and simultaneously retain the sociocultural identity which has survived for centuries and which has influenced countries of both northern and southern hemispheres in their thoughts and actions. The socio-economic improvement of any society relies upon on the increase of better instructional establishments and their involvement in dissemination of two understanding, academic innovative and excellence research and improvement programmes leading to encouraging indigenous generation and developing new products, inculcating entrepreneurship, patents and offerings. Education in India is seen as one of the ways to speed up social mobility. It currently represents a paradox as Indian specialists are taken into consideration many of the first-class inside the international.

\section{Scope of the Study}

Information spread, imagination and development are the existence blood of humanity. Higher instructive establishments assume an essential part in the way of life of people and in the budget of the nation. It's expansive capacity covers the board of advanced education, redirection of advanced quality and education confirmation in advanced education. They include issues of private/public organization, administration and value just as strategy arranging, wellbeing cognizance, physical wellness, proficient morals, esteem instruction and assessment/appraisal framework and the most significant issue of supporting excellence. In creating nations like India, higher instructive establishments assume a fundamental part in the public improvement measure. The higher instructive organizations are encountering mounting understudies' desires each day. Rivalry is blossoming and the progression strategy is quickening at a remarkable rate. The new serious climate squeezes higher instructive foundations to increase the nature of training.

To give quality training, the higher instructive organizations need to endeavor to alter the learning and educating position. In the learning circumstance, the establishments ought to make friendly air by giving best foundation offices, for example, library, lab and so forth. In showing circumstance, the organizations should participate in building up the abilities, skills and capacities of the educators.

To bestow quality instruction, the foundations ought to build up a positive and favorable authoritative atmosphere. The pre-imperative for improving the hierarchical atmosphere is, rehearsing the compelling human asset the executives in higher instructive foundations. It is normal that the results of this investigation will give adequate criticism to improve the human asset the executives rehearses in higher instructive establishments. 


\section{A Renaissance in the Management of HRM in Higher Technical Institutions}

Training is one of the possible components in the mankind. It is likely the fourth need after three essential needs viz. food, dress and safe house. It is a basic human ethicalness. Through hundreds of years, training has been an exceptionally powerful apparatus for mankind in confronting difficulties and encouraging advancement. Training is revamped as one of the basic modules of the public improvement endeavors and advanced education, exactly, is of crucial significant for the country, as it is an incredible asset to assemble information based society of the 21 st century. In the public advancement measure, instruction framework has a significant task to carry out, uniquely the advanced education. After Independence, individuals needed to fabricate a cutting edge, solid, dynamic and independent India which could stand side by side with the created countries.

The Information Technology Revolution is the reformist withdrawal of state Governments from subsidizing advanced education. The private segment was permitted out of a major method to set up Deemed Universities, Professional and Quasi-proficient schools on selffinancing premise. Favorable climate is additionally made for unfamiliar colleges to build up fixates on self-financing. Indeed, even presentation of new courses or projects in State Funded Universities and associated schools which are supported, is permitted distinctly on 'independent' premise, since the year 2000. The charges will be controlled by the 'market powers' and will be high far from the metropolitan and rustic poor. The monetarily and socially helpless youth will be denied of aptitude arranged self-financing courses. Individuals talk about 'consideration' boisterously, yet work on something very surprising. Banks are discovering it monetarily weak as majority of the instructive credits is turning out to be 'Non Performing Assets', making it eventually a backhanded weight on the citizens.

Coming up next are the significant pushes of advanced education in India:

a) To advance discussion and conversation on issues of worry in advanced education at different levels and effectively partake in their consultative systems as a support gathering.

b) To make groundbreaking musings and standards in zones identifying with advanced education including strategy, guideline, vital and operational and along these lines help in building up a fitting advanced education structure.

c) To encourage creation, advancement and development of higher instructive organizations of worldwide greatness by giving a wide range of help including staff improvement, encouraging other formative activities, making of collaboration among foundations and different partners, tending to quality and accreditation issues, among others.

d) To help build up a higher instructive framework that explicitly lines up with employability needs of corporate and different areas.

e) To advance exploration and distribution on contemporary and significant issues of advanced education.

f) To explicitly investigate, evaluate and assess World Trade Organization (WTO) and General Agreement on Trade and administration (GATS) arrangements and their suggestions on advancement of advanced education administrations in India and to make the Indian establishments arranged for the equivalent.

g) To be an autonomous voice of the advanced education network in India; be educated about the worldwide endeavors across countries for advanced education; be a piece of change 
discoursed and contribute as a major aspect of World Trade Organization adjusts identifying with Indian advanced education issues in discussion with individuals from common society.

h) To participate in synergistic concurrences with comparable discussions/foundations/associations in different pieces of the world and advance "greatness in worldwide advanced education".

I) To attempt and do some other action auxiliary and legitimately or by implication identified with the abovementioned, which the gathering may jump at the chance to participate in every now and then in arrangement with its wide vision.

\section{Conclusion}

The socio-economic development of a country largely depends upon the effective organization and implementation of education. In India, education is seen as one of the ways to speed up social mobility and equality. The National Policy on Education visualizes that higher education should become dynamic in terms of consolidation and expansion of institutions, creation of more autonomous colleges and departments, redesigning the existing courses to cater to the needs of the learners, continuous training of teachers in the light of globalization of education, strengthening research and improvement in efficiency. The globalization of schooling at country wide and international tiers permits operative working of organizations giving room to quality development. The best development is the crux of the trouble in Indian higher education. To preserve nice bench mark, there may be a need for effective management between the working essentials in the learning device. The human assets within the company play a tremendous function in conducting the goals and goals of higher training. Possibly, dealing with the human assets is the high goal of an institution inside the context of globalization. The gift examine attempts to discover to what quantity the human resource sports are finished in higher schooling to satisfy the stated objectives and goals. The effects of the observe will be beneficial to the coverage planners to express suitable techniques in strengthening powerful management of manpower properties in better academic organizations.

\section{References}

[1] Dulebohn, J. H.. Ferris G. R \&Stodd J. T. (2015). The history and evolution of human resource management. In Handbook of Human Management, Ferris, G. R. Rosen, S. D. and Barnum, D. T. Eds. Blackwell Publishers

[2] Ehrlich, C.J. (2017). Human resource management: A changing script for a changing world. Human Resource Management, 36 (1), 85-89.

[3] Green, K., Wu, C., Dwayne, W. \&Medin, B. (2016). The impact of strategic human resource on firm performance and HR professional work attitudes and work performance. International Journal of Human Resource Management, 17(4), 559-579.

[4] Jamrog, J.J. \&Overholt, M. H. (2014). Building a strategic HR function continuing the evolution. Human Resource Planning.27, (1), 51-62.

[5] Lee, D. (2005). Hiring the best teachers: Gaining a competitive edge in the teacher recruitment process.Public Personnel Management, 34(3), 263- 269.

[6] Noe, R., Hollenbeck, J., Gerhart, B. \& Wright, P. (2014). Human resource management: Gaining a competitive advantage. Boston: Irwin McGraw Hill.

[7] Patrick, M. \& Hartmann, L. (2019).Human resource management in Australia: Prospects for the twenty-first century," International Journal of Manpower, 22, (3), 198-206. 